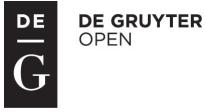

\title{
A European DilemMa: THE EU EXPORT CONTROL REgIME ON DUAL-USE GOODS AND TECHNOLOGIES
}

\author{
Hamed Alavi ${ }^{1}$, Tatsiana Khamichonak ${ }^{2}$
}

\begin{abstract}
Export controls for dual-use items are an important constituent element of both the security policies of state exporters and WMD non-proliferation efforts. Dual-use goods and technologies can be used for both civil and military purposes, which requires careful oversight over their export to countries that are considered unfriendly or have ambiguous foreign policy attitudes. By their very nature, dual-use items may be used both to further legitimate ends, like promoting technological development and strengthening economic ties, and to aid in unwarranted acts. State exporters are faced with the responsibility of balancing the security objectives pertaining to exports of dual-use items with the competitiveness of local economies. The paper discusses the EU export control regime and EU membership in international export control groups. In doing so, comparative and normative research methods are chosen to analyze existing literature on Council Regulation 428/2009 and other international export control groups, including the Wassenaar Arrangement, the Missile Technology Control Regime (MTCR), the Australia Group (AG) and the Nuclear Suppliers Group (NSG). The paper will conclude by identifying shortcomings and addressing possible amendments to the regulation.
\end{abstract}

\section{Keywords}

Dual-use Items, Security Policy, Weapons of Mass Destruction, Export Control

\section{Introduction}

The first attempts to establish a Community regime of export controls for dual-use goods came with the first Council Regulation of $1994^{3}{ }^{4}$ After the Lisbon Treaty included dual-use goods and technologies within the framework of EU trade policy as opposed to the former

\footnotetext{
${ }^{1}$ Tallinn Law School, Tallinn University of Technology, Estonia. E-mail: hamed.alavi@ttu.ee.

${ }^{2}$ Vrije Universiteit Amsterdam, De Boelelaan 1105, 1081 HV Amsterdam, Netherlands. E-mail: tatsiana.khamichonak@hotmail.com.

${ }^{3}$ Council Regulation 3381/94.

${ }^{4}$ Fiott and Prizeman (2013).
} 
common market and competition rules, EU Member States began to relinquish exclusive control over export authorization procedures to the European Commission (hereinafter referred to as 'the Commission'). Since then, the regime has experienced a gradual shift of competences, with a lot more control vested in the Commission's decisions. At present, all non-EU transfers of the indicated items require a permit in the form of an authorization license, whereas the circulation of dual-use goods within the Union has been simplified and to a certain extent harmonized. The intra-EU regulation is not without its flaws: for instance, harmonization is administered according to the lowest common denominator of the respective national provisions across the Member States.

The paper discusses the status quo of the EU export control regime and its relatively short legislative history. Specifically, Council Regulation 428/2009 setting up a Community regime for the control of exports, transfer, brokering and transit of dual-use items ${ }^{5}$ is analyzed. Further, the paper seeks to uncover the role of the major export control groups - the Wassenaar Arrangement, the Missile Technology Control Regime (MTCR), the Australia Group (AG) and the Nuclear Suppliers Group (NSG) - and their relevance to the creation of regulated lists. Finally, the paper addresses potential amendments to the regime based on its identified shortcomings.

\section{International EU commitments in the framework of export controls}

Export controls are a trade instrument designed to ensure international security objectives in the framework of the non-proliferation of weapons of mass destruction (hereinafter referred to as "WMD"). The state of peace is threatened by the emergence and development of terrorism as well as the willingness of state and non-state actors to come into possession of WMD and complementary technologies. Current international and domestic systems regulating WMD non-proliferation may be brought into question and considered insufficient in light of the nuclear capability of India, Israel, Pakistan and North Korea. Moreover, in the 1980s the European system of export controls, its monitoring and implementation, was brought into the spotlight when sensitive items were smuggled from within the EU by individuals and companies. The UN Security Council has repeatedly pointed out that the proliferation of nuclear, chemical and biological weapons constitutes a threat to international peace and security. ${ }^{6}$ In Resolution 1540, the Council addressed the Member States with a call to not offer any support to non-state actors seeking to acquire WMD. To this end, the Member States shall establish effective domestic non-proliferation controls as well as reinforce their international commitments. ${ }^{7}$

Within the framework of WMD non-proliferation efforts, a strong system of controls over the export of dual-use goods and technologies is a vital constituent element. According to the Commission's estimate, more than 5,000 companies in the EU are involved in the export of dual-use goods and technologies, with up to $10 \%$ of overall European exports allocated

\footnotetext{
${ }^{5}$ Council regulation (EC) No 428/2009.

${ }^{6}$ UNSC Resolution 687 (1991).

${ }^{7}$ UNSC Resolution 1540 (2004).
} 
to dual-use items. ${ }^{8}$ Regulation $428 / 2009$, setting up the Community export control regime (hereinafter referred to as 'Regulation 428/2009'), indicates in Annex I the scope of the interpretation of dual-use goods. It is clear that the concept covers industries ranging from nuclear, biological and chemical, to computers and telecommunications, to navigation and avionics, among others. Dual-use goods are high-tech items that are not available generally but can only be obtained from a limited number of state exporters, many of whom are members of the four international export control regimes: the Australia Group, the Missile Technology Control Regime, the Nuclear Suppliers Group and the Wassenaar Arrangement. Ideally, state exporters are committed to preventing the use of dual-use goods and technologies for military purposes, including the creation of WMD. ${ }^{9}$ A number of sensitive items still circulate the global market due to inefficient or absent controls in the state exporters that have established no such commitments. Situations in which dual-use items are available on the global market outside of the system of commitments of the international export control regimes raises the question of the need and extent of their regulation by the EU. While the need to uphold security objectives is paramount, they shall be properly balanced with the economic development and competitiveness of European exporters on the global market.

In 2003 the European Council adopted the European Security Strategy (hereinafter referred to as the 'ESS' $)^{10}$, which places WMD proliferation at the top of the list of potential threats to security, outscoring terrorism, organized crime, regional conflicts and state failure. Together with the ESS, the Council adopted the WMD Strategy and the Plan of Action ${ }^{11}$, which aim at implementing and strengthening of the European WMD non-proliferation strategy with all relevant instruments ${ }^{12}$, i.e. nationally- and internationally-coordinated export controls, multilateral treaties, verification mechanisms and threat reduction programs. ${ }^{13}$ Specifically, the Strategy mentions strengthening export control strategies and practices in cooperation with partners; reinforcing the efficiency of export controls in the enlarged Europe; providing assistance with technical knowledge in the area of export controls; reinforcing export controls with regard to intangible transfers of dual-use technology and facilitating information exchange between Member States. ${ }^{14}$

Since the adoption of the WMD Strategy in 2003, enlargements have stretched the EU's borders to include 28 Member States, as a result of which the inner dynamics of the Union have changed and the efficiency of the system of export controls has been questioned. ${ }^{15}$ This is the case because of the drastically different status of export control regulations in the acceded states - many of them lacked effective export control regimes and did not belong to the four international export control groups. ${ }^{16}$ With this enlargement, the

\footnotetext{
${ }_{8}^{8}$ European Commission Green Paper COM (2011) 393 final.

${ }^{9}$ Ibid., p. 4.

${ }^{10}$ A Secure Europe in a Better World.

${ }^{11}$ EU strategy against proliferation of Weapons of Mass Destruction, 15708/03.

${ }^{12}$ Chapter III of the WMD Strategy, also referred to as the 'living action plan'.

${ }^{13}$ Ibid., § 29.

${ }^{14}$ Idid., § 30(4).

${ }^{15}$ Anthony and Grip (2013).

${ }^{16}$ Ibid., p. 17.
} 
requirement of the overall enhancement of the European export control policies under the WMD Strategy became problematic. Moreover, since accession to the EU meant participation in the common market, where the free circulation of dual-use items was established, the immature export control systems in the new states could potentially create a proliferation threat. In order to level the playing field, a peer review of export control regimes in the former and new states was carried out in 2005-2006. ${ }^{17}$ In 2008 the 'Conclusions and new lines for action by the European Union in combating the proliferation of weapons of mass destruction and their delivery systems' was adopted as the next step in promoting and facilitating the implementation of the WMD Strategy. ${ }^{18}$ The conclusion reaffirmed that misappropriated WMD constitute 'one of the greatest security challenges which Europeans may ever face'. ${ }^{19}$ The WMD Strategy remains utterly relevant today and ever more important, as it realizes the guidelines of UN Resolution 1540, which is the cornerstone of international non-proliferation efforts. ${ }^{20}$

\section{The contribution of the $\mathrm{EU}$ in international export control groups}

The Member States and/or the EU in its own capacity are members of the Australia Group, the Wassenaar Arrangement, the Missile Technology Control Regime and the Nuclear Suppliers Group - the four major international export control regimes.

The Australia Group (AG) is an informal commitment, through which countries undertake to ensure that exports do not contribute to the development of chemical and biological weapons. This is realized by harmonizing national export control measures in pursuit of the fulfilment of their obligations under the Chemical Weapons and Bio- and Toxic Weapons Conventions. All the AG participants are State Parties to both Conventions and the 1925 Geneva Protocol. The first meeting of the then 15 participants and the European Commission took place in 1985 in Brussels as a response to the 1984 UN discoveries of Iraq's use of chemical weapons (nerve agents and sulphur mustard) in violation of the 1925 Geneva Protocol. With the evolution of threats and the variety of the dual-use materials that can be used in the production of chemical and biological weapons, specific biological agents were included in the scope of AG cooperation in the early 1990s. The harmonization of exports among AG members is achieved through the licensing of exports of certain chemicals, bio-agents and dual-use chemical and bio-manufacturing facilities. The number of AG members has grown from 15 in 1985 to 41 and includes the EU as a member in its own right. ${ }^{21}$

The Wassenaar Arrangement (WA) on Export Controls for Conventional Arms and DualUse Goods and Technologies is an intergovernmental arrangement established in July 1996 by 33 states including the US, Great Britain, Russia, France, Canada and Japan. ${ }^{22}$

\footnotetext{
${ }^{17}$ Ibid., p. 18.

${ }^{18}$ Council Conclusions 17172/08.

${ }^{19}$ Ibid., p. 3.

${ }^{20}$ Ibid., p. 4.

${ }^{21}$ Australia Group (2007).

22 August, Mayer and Bixby (2013).
} 
The WA replaced CoCom, which was no longer considered to be an appropriate basis for export controls, but unlike CoCom, WA is open to all countries on a non-discriminatory basis, and is not directed against any state or group of states, and many former Warsaw Pact countries are now members of WA. WA members undertake to ensure that transfers of conventional arms and dual-use items do not contribute to the development of military capabilities and do not undermine international and regional peace and security. ${ }^{23}$ The WA particularly seeks to complement and reinforce the existing control regimes for WMD and their delivery systems; enhances cooperation to prevent the acquisition of arms and dual-use items by terrorist groups and organizations as well as by states and other endusers, if the situation in the region becomes a cause of serious concern. ${ }^{24}$ As of 2012, the number of WA participants had increased to 41 states, with the European Commission participating within the delegations of EU presidencies.

The Missile Technology Control Regime (MTCR) is an informal association of states established by Canada, France, Germany, Italy, Japan, the UK and the US in 1987. The association facilitates WMD delivery and coordinates the participating states' national licensing efforts. After the events of $9 / 11$, the focus has also been directed on the prevention of WMD proliferation by terrorist groups and individuals, by monitoring the transfers of missile equipment, material and related technologies capable of delivering WMD. The MTCR has no permanent organization. Its activities are based on the MTCR Guidelines and the Equipment, Software and Technology Annex, which lay down rules of participation and export control guidelines for the Annex items. Currently, there are 34 members, with the European Commission participating within the delegations of EU presidencies.

The Nuclear Suppliers Group (NSG) is a group of nuclear supplier countries that aims at the non-proliferation of nuclear weapons. The NSG operates by the Non-Proliferation Principle through the implementation of two sets of Guidelines for nuclear and nuclearrelated exports, which implement various binding international instruments in the field of nuclear non-proliferation: the Treaty on the Non-Proliferation of Nuclear Weapons (NPT), as well as a number of regional agreements. The NSG was created in 1974 following the Indian nuclear explosion, which showed that nuclear technology transferred for peaceful purposes can be misused. In 2013, there were 46 members with the European Commission and the Chair of the Zangger Committee ${ }^{25}$ participating as observers. $^{26}$

\footnotetext{
${ }^{23}$ August, Mayer and Bixby (2013), p. 396.

${ }^{24}$ Council on Foreign Relations (2015).

${ }^{25}$ The Zangger Committee, a.k.a. Non-Proliferation Treaty Exporters' Committee, was established in 1971, one year after the NPT came into force. The Committee coordinated the Member States' interpretations of the NPT's export control provision, which requires exporters to seek International Atomic Energy Agency's (IAEA) safeguards in order to supply nuclear items that are capable of the 'processing, use, or production of special fissionable material'. The Zangger Committee is less active now with the creation of the NSG. See August, Mayer and Bixby (2013), p. 397.

${ }^{26}$ See Nuclear Suppliers Group (2015).
} 


\section{Shaping the export control regime in the $\mathrm{EU}$}

Regulation 428/2009 is the cornerstone of the EU export control regime. It is binding and directly applicable, and establishes common control rules and a list of controlled items common throughout the EU. However, the adoption of policies to implement the Regulation's provisions is left to the Member States. The Regulation is part of the EU's Common Commercial Policy, coming under the Union's exclusive competence. This means that the Member States are precluded from legislating in this area unless specifically authorized. ${ }^{27}$ This has not always been the case, however, and the limited authority of the Member States is a result of a shift of competences to the EU, which was characteristic of the history of the Regulation's adoption.

\section{Historical developments before the coming into force of Regulation No. 428/2009}

Earlier, WMD non-proliferation and harmonization of the Member States' national export controls systems was carried out through their participation in international agreements. During the Cold War, the Western states established in 1949 at the initiative of the US the Coordinating Committee for Multilateral Strategic Export Controls $(\mathrm{CoCom})^{28}$ in order to align their export control efforts directed against the Warsaw Pact ${ }^{29}$ states. CoCom, with its headquarters in Paris, was created between the US, Japan and the NATO states except Iceland and meant to shield important western technologies from the reach of the Eastern bloc. To this end, CoCom operated three lists of items that were prohibited from exportation to the Soviet Union or its allies. ${ }^{30}$

The European Member States participated in CoCom on their own behalf with the exclusion of European institutions, which created divergent individualistic systems of export controls and adversely impacted intra-community and external trade. ${ }^{31}$ There was thus no harmonized Community regime of export controls, which compromised the free movement of goods in the internal market and impaired internal trade. Recognition of the lack of coordination between the Member States regarding the regulation of export controls was achieved when certain goods headed from France to Moscow were seized in Luxembourg airport due to inaccurate documentation, the case of Aimé Richardt and Les accessoires scientifiques $S N C^{32}$. Mr. Richardt, the director of Les Accessoires Scientifiques, established in France, prepared to deliver a ten-inch Veeco Microetch (used in the production of bubble memory circuits) to Technopromimport, established in Moscow. After the necessary formalities were completed in France, the direct Paris-Moscow flight was cancelled and the

\footnotetext{
${ }^{27}$ Article 2(1) and Article 3(1) TFEU.

${ }^{28}$ Micara (2012), pp. 578-593.

${ }^{29}$ The Warsaw Treaty Organization, a.k.a. the Warsaw Pact, was a political and military alliance between the USSR, Albania, Poland, Czechoslovakia, Hungary, Bulgaria, Romania, and the German Democratic Republic, established in 1955 to counterbalance NATO. The Pact was terminated in July 1991 with the collapse of the Soviet Union.

${ }^{30}$ Gregory (1987), pp. 863-882.

${ }^{31}$ Micara (2012), p. 581.

${ }^{32}$ Case C-367/89 Richardt and 'Les accessoires scientifiques' [1991] ECR.
} 
item was transported by lorry to Luxembourg airport, where it was seized. The seizure occurred because the item was claimed to be accompanied by 'inaccurate declarations in order to conceal its strategic nature and to permit its transit to the USSR', which was contrary to Luxembourg laws that required a special transit license. ${ }^{33}$

The Court of Justice of the European Union (CJEU) ruled that Luxembourg was entitled to require special authorization for the transit of the said item and its subsequent confiscation was justified. ${ }^{34}$ The Court referred in its argumentation to Article 36 of the EEC Treaty, which provides that Member States may derogate from the principle of free movement of goods in certain cases ${ }^{35}$ and by doing so, employ measures that serve the objective and do not restrict intra-Community trade more than absolutely necessary ${ }^{36}$ in cases where the pursued objective concerned the internal as well as external security of the state of Luxembourg, which could be jeopardized by the transit and export of dual-use goods. Overall, the judgment was a reminder that the internal market lacked an integrated and harmonized system of export controls for dual-use items.

Shortly after Richardt, the Commission submitted in 1992 a Proposal for a Regulation on the control of exports of certain dual-use as well as nuclear goods and technologies. ${ }^{37}$ The primary objective of the Proposal was integrating dual-use goods and technologies into the common market by eliminating border controls between the Member States and strengthening control over exports to non-EU countries. The Proposal listed five criteria for border controls between the Member States to be abolished: the common list of dual-use goods subject to control; the common list of destination countries; common criteria for issuing export licenses for third-country exports; a mechanism for the coordination and enforcement of licenses; procedures for administrative cooperation between the licensing authorities and customs offices. ${ }^{38}$

The Proposal was followed by Council Regulation No. 3381/94, which was adopted under Article 113 of the EC Treaty and became part of the EU Common Commercial Policy (CCP). In parallel with the regulation, the Council adopted within the framework of the EU Common Foreign and Security Policy (CFSP) Decision 94/942/CFSP on the Joint Action. The Joint Action created a list of controlled items corresponding to the understanding of the international export control groups and which should have been accounted for by the Member States when granting licenses; the Regulation established a system of licenses for dual-use items. The Regulation and the Decision on Joint Action coexisted, regulating identical issues, but did not overlap due to their different legal bases. Even though conflicting with regard to, primarily, decision-making, the two instruments were meant to be an 'integrated system' ${ }^{39}$ and eliminate the concerns raised in the Richardt case through the mutual recognition of licenses. ${ }^{40}$ The conflict of interest occurred because

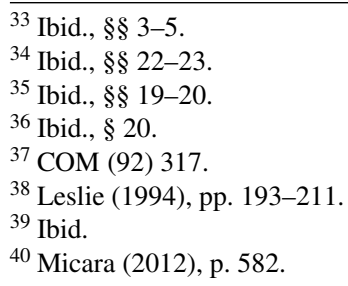


Article 113 of the EC Treaty prescribed for decisions about certain sensitive matters to be made under the Qualified Majority Voting (QMV). The Member States preferred not to rely on this and eventually surrender their competence to the Commission, which favored a single European strategy in the area of export controls of dual-use goods. ${ }^{41}$

The two-tier system of export controls was amended after two key CJEU judgments Leifer and Werner - in which the Court ruled that exports of dual-use items must be allocated exclusively under the CCP because by their very nature they constitute trade measures as opposed to measures having security and foreign policy objectives. ${ }^{42}$ The CCP falls under the exclusive competence of the EU, precluding the Member States from legislating in the area without authorization. ${ }^{43}$ No longer blocked by the decision-making deadlock, the Commission stressed that a pan-European systems of export controls was necessary for two major reasons. Firstly, it would eliminate obstacles to the free movement of dual-use items in the common market and form strong boundaries on the frontiers. Secondly, it would provide greater legal certainty and transparency and reduce the burden on exporters. ${ }^{4}$

The two-tier system of rules was unified in one instrument in the year 2000 when the Decision on Joint Action was repealed and a new Regulation 1334/200 was adopted under Article 113 of the EC Treaty. While establishing a common export controls regime in the EU, the Regulation meant that the lists of controlled items could now only be amended as part of Commission proposals to amend the Regulation. This could be viewed as constrained in light of the fact that the Commission only participates in the Australia Group in its own right, whereas the amendments to control lists are carried out based on the respective agreements of the Member States with the international export control groups. The unification of the EU export controls regime in one instrument has also not eliminated the proliferation concerns related to the accession of the new Member States during the enlargement waves in 2004 and 2007, with their unequal membership international export control groups. ${ }^{45}$ The Proposal to amend Regulation 1334/2000 ${ }^{46}$ was submitted by the Commission in December 2006, following the 2004 peer review of the Regulation's implementation by the Member States.

The Proposal was made in compliance with the Thessaloniki WMD Strategy and Action Plan and sought to further strengthen the EU system of export controls of dual-use items, offer greater transparency and decrease regulatory burdens for EU exporters in implementing the export controls requirements. The Proposal was designed to create 'the EU of high technology jobs' and increase the competitiveness of EU industries while balancing these goals with the international non-proliferation commitments and the objectives of the EU WMD Strategy. ${ }^{47}$ The Proposal's five major changes, which went beyond technical revision, included the following: adoption of the 'comitology' procedure for the

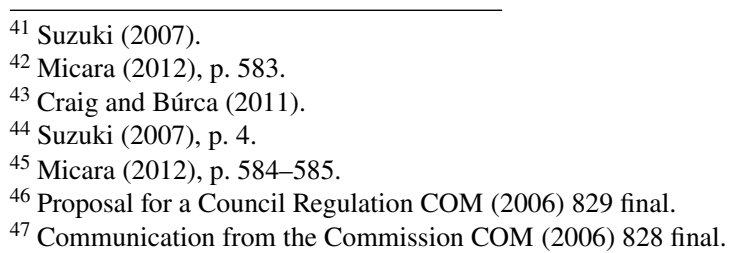


amendment of annexes; replacement of the authorization requirement for Annex $\mathrm{V}$ items with a pre-notification procedure; introduction of appropriate civil and criminal penalties to be applied by the Member States for violation of the Regulation's provisions; legal security for the export of dual-use items, particularly with respect to third-country legislations; and lastly, introduction of a negotiation mechanism with third-countries concerning such issues as re-export requirements. ${ }^{48}$ The proposed comitology procedure was, however, rejected by the Council, despite the fact that it could have potentially facilitated the process of updating the lists of control items to bring them in line with the international export control regimes. ${ }^{49}$

\section{The important issues covered in Regulation 428/2009}

The Recast Regulation 428/2009 was adopted in May and entered into force in August 2009. It reinforced the Community General Export Authorization (CGEA) for non-EU transfers of certain items, the list of which is set out in Annex II. ${ }^{50}$ Article 9(2) and Annex III provide that for all other exports that are subject to an authorization requirement, exporting companies shall obtain licenses, which is meant to prevent them from cherrypicking and exporting from a Member State with less stringent requirements. ${ }^{51}$ Therefore, there are four types of licenses under the EU export control regime. 1) The CGEA allows exporting certain dual-use items to certain destinations under certain conditions. There are currently six CGEAs: exports to Australia, Canada, Japan, New Zealand, Norway, Switzerland, Liechtenstein and the US; exports of some types of dual-use items to identified destinations; exports after repair or replacement; temporary exports for exhibition or fair; telecommunications; and chemicals. ${ }^{52}$ 2) National General Export Authorizations (NGEA) shall be issued by Member States to exporters established or resident in the authorizing state if they do not overlap with items listed in part 2 of Annex II, and/or meet the requirements set out in the Regulation and national legislation. ${ }^{53}$ Currently, NGEAs are applied in France, Germany, Greece, Italy, Sweden, the Netherlands and the UK. ${ }^{54}$ The Commission shall be notified of any NGEA issued or modified by a Member State. 3) Global Export Authorizations cover several items in several countries of destination or several end-users. 4) Individual licenses are granted by national authorities to an exporter to cover exports of one or more dual-use items to one end-user in a non-EU country. All four types of licenses are granted or denied by the Member State authorities, whereas it is required to notify the Commission of export license refusals. ${ }^{55}$

Article 4 read in conjunction with Article 8 of the recast Regulation introduces a socalled 'catch-all' clause, which allows Member States to impose a restriction on exports of dual-use items that are not covered by Annexes I and IV, for national security and

\footnotetext{
${ }^{48}$ Ibid., p. 8.

${ }^{49}$ Micara (2012), p. 588.

${ }^{50}$ Council Regulation No 428/2009, Article 9.

${ }^{51}$ Fiott and Prizeman (2013), p. 16.

${ }^{52}$ European Commission Factsheet 07/02/2014.

${ }^{53}$ Article 9(4).

${ }^{54}$ Commission factsheet, supra note 7.

${ }^{55}$ Fiott and Prizeman (2013), p. 16.
} 
public policy reasons. In particular, Article 4(1) reads that authorization for unlisted items may be required if the exporter has information that the items may be intended for the production and development of chemical, biological or nuclear weapons, other nuclear explosive devices or missiles capable of delivering such weapons. Also, authorization shall be required if unlisted items are meant to be transferred to a country subject to an arms embargo and when the exporter has information that the items are intended for 'military end-use'.

At present, the EU regime of export control of dual-use items consists of Regulation (EC) No. 428/2009 and the Council Joint Action 2000/401/CFSR ${ }^{56}$. EU export controls are claimed to be 'the closest thing there is to a unified export control regime'. ${ }^{57}$ The Regulation is binding and directly applicable in the Member States, whereas the Joint Action is an intergovernmental cooperation instrument, which was adopted under the TEU provisions, and which has to be transposed into the Member States' national legislations. ${ }^{58}$ The Regulation has subsequently been substantially amended by Council Regulation (EC) No. 1232/2011, and the items listed in Annex I of the Regulation were amended by Council Regulation (EC) No. 388/2012 after the review of the control lists of the Wassenaar Arrangement, the Australia Group, the Missile Technology Control Regime and the Nuclear Suppliers Group during 2009-2010.

In Article 25 the Regulation provides that every three years the Commission shall review its implementation in the Member States and identify possible areas of reform. A public consultation with the stakeholders was launched in 2011 regarding the functioning of the current EU export controls regime. ${ }^{59}$ It reaffirmed that a major challenge for an efficient export controls systems is the need to balance the foreign and security objectives with economic considerations. The results of the consultation identified some major challenges in the existing export controls framework, including the growing importance of emerging economies, the emergence of new and advanced technologies and the evolution of security risks and threats (terrorism and acquisition by State and non-state actors of WMD). ${ }^{60}$ The outcomes of the public consultation as well as the amendments to the lists of controlled items in 2011 and 2013 led to a new Commission Proposal in October 2014 to amend Annex I of Regulation 428/2000. ${ }^{61}$

\section{Conclusion}

In the course of the historic formation of the European regime of export controls for dual-use goods and technologies, the Member States have gradually surrendered their decision-making competences to the Commission. However, despite the fact that a common export controls regime has been created in the EU, there is a need for a more integrated and harmonized system in light of the discrepancies in economic and technological

\footnotetext{
${ }^{56}$ Council Joint Action 2000/401/CFSP, L 159/216.

${ }^{57}$ Chapman (2013).

${ }^{58}$ Michel (2014).

${ }^{59}$ COM (2011) 393 final.

${ }^{60}$ Commission Staff Working Document SWD (2013) 7 final.

${ }^{61}$ Commission Delegated Regulation C (2014) 7567 final.
} 
development between the older and more recently acceded Members. Specifically, adequate information-sharing and transparency among the Member States and closer cooperation with the private sector is required. This could potentially include the 'E-licensing system' for simplifying administrative procedures and data exchange, as well as the possible introduction of European General Export Authorizations (EGEAs) for facilitating low-risk trade among European companies. The authors are of the opinion that an adequate response to the current challenges in the EU export controls regime should shed light on gloomy areas of its performance, including human security, intangible means for technology transfer, technical advancements and the unclear legal terminology which exists in the very text of the regulation. The promotion of further cooperation among partner countries, the establishment of an ongoing dialogue between trading partners, initiating a shift towards the model of global governance; increasing harmony amongst EU member states; providing a more efficient definition for investigative measures of in transit and transshipment controls, solving problems in the enforcement of controlling measures, and further improvement of collaboration with exporters - all of these are matters to be considered in the future revision of the current regulation or introduction of a new European Export Control Regime on dual-use items.

\section{References}

A Secure Europe in a Better World. European Security Strategy, Brussels, 12 December, 2003.

Anthony, I., Grip, L. (2013). Strengthening the European Union's Future Approach to WMD non-proliferation. SIPRI Policy Paper No. 37.

August, R., Mayer, D., Bixby, M. (2013). International Business Law. 6th ed., Pearson Education Limited, England.

Australia Group. (2007). Retrieved from http://www.australiagroup.net/en/index.html.

Case C-367/89 Richardt and 'Les accessoires scientifiques' [1991] ECR.

Commission Delegated Regulation C (2014) 7567 final, amending Council Regulation (EC) No 428/2009 setting up a Community regime for the control of exports, transfer, brokering and transit of dual use items, Brussels, 22. 10. 2014.

Commission Staff Working Document, SWD (2013) 7 final, Strategic export controls: ensuring security and competitiveness in a changing world. A report on the public consultation launched under the Green Paper COM (2011) 393, Brussels, 17. 1. 2013.

Communication from the Commission COM (2006) 828 final, on the Review of the EC Regime of Controls of Exports of Dual-Use Items and Technology, Brussels, 18. 12. 2006. Council Conclusions 17172/08, Brussels, 17 December, 2008.

Council Joint Action 2000/401/CFSP, L 159/216 of 22 June, 2000, concerning the control of technical assistance related to certain military end-uses.

Council on Foreign Relations. (2015). Wassenaar Arrangement Guidelines \& Procedures, including the Initial Elements, 1996 with amendments. Retrieved from http://www.cfr.org/ arms-industries-and-trade/wassenaar-arrangement-guidelines-procedures/p28092. 
Council regulation (EC) No 428/2009 of 5 May, 2009, setting up a Community regime for the control of the export, transfer, brokering and transit of dual-use items (Recast). OJ L 134 29. 5. 2009.

Council Regulation No 3381/94 of 19 December, 1994, setting up a Community regime for the control of exports of dual-use goods.

Council Regulation No 428/2009 of 5 May 2009, setting up a Community regime for the control of exports, transfer, brokering and transit of dual-use items, Article 9.

Craig, P. and Búrca, G. (2011). EU Law: Text, Cases and Materials. 5th ed., Oxford University Press, Oxford, UK.

EU strategy against proliferation of Weapons of Mass Destruction, 15708/03, Brussels, 10 December, 2003.

European Commission Factsheet 07/02/2014, on The EU Dual Use Export Control Regime.

European Commission Green Paper COM (2011) 393 final, The dual-use export control system of the European Union: ensuring security and competitiveness in a changing world. Fiott, D., Prizeman, K. (2013). The Arms Trade Treaty and the Control of Dual-Use Goods and Technologies. IES Working Paper 1/2013, Institute for European Studies, VUB, Belgium.

Gregory, J. E. (1987). Controlling the Transfer of Military Significant Technology: COCOM After Toshiba. Fordham International Law Journal, 11(4), 863-882.

Chapman, B. (2013). Export Controls: A Contemporary History. University Press of America, Inc.

Leslie, B. J. (1994). Dual Use Goods and the European Community: Problems and Prospects in Eliminating Internal Border Controls on Sensitive Products. Boston College International and Comparative Law Review, 17(1), 193-211.

Micara, A. G. (2012). Current Features of the European union regime for Export Control of Dual-Use Goods. Journal of Common Market Studies, 50(4), 578-593.

Michel, Q. (2014). The European Union Dual-Use Items Control Regime, Comment of the Legislation article-by-article, ESU Non-Proliferation, January 2014.

Nuclear Suppliers Group. (2015). Retrieved from http://www.nuclearsuppliersgroup.org. Proposal for a Council Regulation COM (2006) 829 final, setting up a Community regime for the control of exports of dual-use items and technology, Brussels, 18. 12. 2006.

Suzuki, K. (2007). Between Trade and Security: EU's Export Control Regime and Its Global Role. Paper for EUSA Tenth Biennial International Conference, May 17-May 19, 2007, Montreal, Canada.

UNSC Resolution 1540 (2004).

UNSC Resolution 687 (1991). 